\title{
A VASBETON SILÓK REPEDÉSEI ÉS EGY'́B PROBLÉMÁI
}
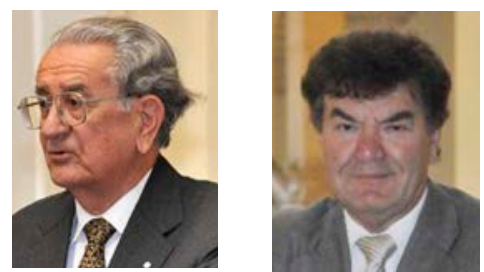

Dulácska Endre - Bódi István

A silók általában 5-10 méter átméröjü, 10-40 méter magas csőszerü létesitmények, melyeket különbözö porszerü, vagy szemcsés anyagok tárolására szoktak használni. A leggyakoribb a különbözö szemes termények, gabonák tárolására szolgáló siló. Ilyen silókat már az 1800-as években alkalmaztak, ezeket kezdetben fából, falazatból, ritkán fémböl készitették. Az 1916 évi felmérés már 330000 silót talált a világon.

A vasbeton 1900 körüli feltalálása után kezdtek elterjedni a vasbeton silók, kezdetben dobozos, később 15$20 \mathrm{~cm}$ falvastagságú, hengeres héjszerkezeti megoldással.

Az elkészült silók átadása utáni időben észlelték, hogy azokon rendszeres repedéskép alakul ki. A silóknak külsö felületén, föleg az alsó harmadában függöleges repedések, míg sokszor az egész magasság mentén, 2-3 méterenként vízszintes repedések jelentkeztek a Magyarországon épült silók jelentös részénél. A függöleges repedések zöme a siló magasságának alsó egyharmadában jelentkezett, ahol a belsö nyomások a legnagyobbak, és a siló önsúlyából, és a tárolt gabona súrlódásából származó nyomás is jelentős.

A vizsgálat kimutatta, hogy a hazai silók 85\%-a repedezett, és a repedezettség számos más országban is rendszeres jelenség, a különbözö üzemi állapotokban. Megállapitotta a jelentés, hogy repedésmentes siló gyakorlatilag nem létezik. A repedésképzödésnek számos oka lehet, és a tönkremenetelt megelözö repedéstágasságok 5-7 mm között voltak.

Jelen dolgozat a vasbeton szerkezetü, körhenger kialakítású silókkal és azok károsodásaival foglalkozik.

\section{BEVEZETÉS}

A silók általában 5-10 méter átmérőjü, 10-40 méter magas, csőszerü létesítmények, melyeket különböző porszerü, vagy szemcsés anyagok tárolására szoktak használni. A leggyakoribb a különböző szemes termények, gabonák tárolására szolgáló siló. Ilyen silókat már az 1800-as években alkalmaztak, ezeket fából. falazatból, ritkán fémből készítették. A tárolt anyagok be- és kitárolása egyaránt a silók felső végén történt. Az 1885. évi listán az USA-ban 2000 ilyen silót tartottak nyilván. Az első siló konferencia 1907-ben volt Chicagóban. Az 1916 évi felmérés 330000 silót talált a világon.

A vasbeton 1900 körüli feltalálása után kezdtek elterjedni a vasbeton silók, kezdetben dobozos, később 15-20 cm vastagságú hengeres héjszerkezeti megoldással. A silók lábra állításával pedig megoldották az alsó, ömlesztett kitárolást az alsó tölcséren keresztül.

Már a 2. világháború előtt épültek Magyarországon vasbetonsilók, így Budapesten (1910-11), Dombóváron (Eszterházy siló) (1924), Karcagon és Szolnokon (1938-1940).

A háború után, 1960-ban megkezdődött a vasbetonsilók sorozatos építése, és 1986-ig 55 silótömb épült. A siló méretezésére TTI segédlet (Bölcskei-Orosz, 1970). készült, oktatása pedig (rövid anyagként) bekerült a rendszeresített egyetemi tananyagba (Bölcskei-Orosz, 1972).

Az elkészült silók átadása utáni időben észlelték, hogy azokon rendszeres repedéskép alakul ki. A silóknak külső felületén, főleg az alsó harmadában függőleges repedések, míg sokszor az egész magasság mentén, 2-3 méterenként vízszintes repedések jelentkeztek a Magyarországon épült silók jelentős részénél. A függőleges repedések zöme a siló magasságának alsó egyharmadában jelentkezett, ahol a belső nyomások a legnagyobbak, és a siló önsúlyából, és a tárolt gabona súrlódásából származó nyomás is jelentős.

A repedések miatt több alkalommal bírósági eljárás is indult, (pl. Dulácska,1991, 1992). A repedések vizsgálata céljából az Építéstudományi Intézet (ÉTI) széleskörű vizsgálatot végzett (Pálossy L, ÉTI, 1989/a-b). A vizsgálat kimutatta, hogy a hazai silók $85 \%$-a repedezett, és a repedezettség számos más országban is rendszeres jelenség (USA, Ausztrália, Svédország, Ausztria, Lengyelország) a különböző üzemi állapotokban. Megállapította a jelentés, hogy repedésmentes siló gyakorlatilag nem létezik. A repedésképződésnek számos oka lehet, és a tönkremenetelt megelőző repedéstágasságok 5-7 mm között voltak. A silók meghibásodási okainak típusai a következők:

- alulméretezés, kevés gyürüirányú vas, ill. gyürüvas toldási hiba miatti oldalfalmegnyílás,

- túlzott repedésmegnyílás, és emiatt beázás, ill. vaskorrózió.

- Betontechnológiai hibák, lokális betonhibák, helyi betontörés függőleges nyomásra.

- Be- és kitároláskor elkövetett üzemeltetési hibák.

- A betároláskor jelentkező nagymértékü süllyedés (20-100 $\mathrm{cm}$ !)

- Porrobbanás miatti cellafelnyílás. (Szabadegyháza).

- Agyagtalajon álló siló felborulása (Algéria).

A Pálossy, 1989/a-b) anyagok alapot adtak a Gabona Tröszt vasbetonsilókra vonatkozó házi szabványának elkészítésére. (Gabona Tröszt, Házi Szabvány, 1989).

Az újabb időben a vasbetonsilókat kezdik kiszorítani a 
fémszerkezetü silók. A jelen dolgozat a vasbeton szerkezetü, körhenger kialakítású silókkal foglalkozik.

\section{A SILÓNYOMÁS}

A silóban tárolt gabona a siló falára horizontális irányú oldalnyomást (silónyomás) fejtki, a súrlódás következményeként pedig függőleges nyomást ad le a falra. A kezdeti időkben a silókat a Janssen által felállított elmélet alapján számították (Bölcskei-Orosz, 1970). Miután az így méretezett silókon meg nem engedhető repedések léptek fel, kutatni kezdték, hogy helytálló-e a Janssen elmélet szerinti méretezés.(BinnewiesHille 1983), (Rosemeier, 1986), (Pálossy L, ÉTI, 1989/a-b), (Orosz, 1998). 1975-től kezdődően mérődobozokkal sikerült kimérni a silónyomást. Megállapították, hogy a nyomás a tárolt gabona tulajdonságain kívül a be- és kitárolási technológiától is függ, és az ürítéskor fellépő nyomás másfél-kétszerese a betárolási nyomásnak. (Kollár, 1989). (Ez a dolgozat bő irodalomjegyzéket is tartalmaz.) Az is előfordult, hogy betonhiba miatt a függőleges teher okozott betontörést a vasbeton silófalban (Dulácska, 1991).

Azt is meghatározták a mérési adatok alapján, hogy a nyomás megoszlása a kör alakú cellákban rendszerint nem centrikus, a különbözö belső átboltozódások és belső dinamikus mozgások miatt.

\section{A VASBETON SILÓK VASALÁSA}

Az 1960-as évek elején a 7,3 m belső átmérőjű silók gyürüvasalása általában kétoldali Ø8 vasalás volt, $20-25 \mathrm{~cm}$ osztástávolsággal. A periodikus betonacél minősége B 45.30, vagy B 60.40 volt. Utólag ránézésre nem lehet a bordázat alapján megítélni a minőséget, mert a melegen hengerelt betonacélok MSZ 339-68 szabványa ugyan megadta a különböző borda típusokat, de nem rögzítette, hogy melyik acélminőséghez melyik bordázat tartozik. Éppen ezért írta elő a megépült építményekre vonatkozó TSZ 01-2013 MMK szabályzat, hogy ellenőrző szakítóvizsgálat hiányában csak a B 45.30 acélhoz tartozó $280 \mathrm{~N} / \mathrm{mm}^{2}$ határfeszültséget (tervezési szilárdságot) szabad figyelembe venni. Az 1980-as évekre a B45.30 betonacél megszünt, így a 80 -as években épült silók betonacélminősége B 60.40 , vagy B 60.50 . Később a silók vasalását sokszor erősebbre tervezték, Ø8 helyett $\varnothing 10-12$ vasalással. A felülvizsgálatok során többször azt tapasztalták, hogy a vízszintes acélbetétek távolsága a tervezettnél nagyobb volt.

\section{A VASBETON SILÓK BETONJA}

A silókat rendszerint csúszó zsaluzattal építették. Ennek a technológiai előnyei mellett több hátránya is volt. A csúszó zsaluzat emelő acélrudazata emelés után üreget hagy a betonban. Az is előfordulhatott, hogy valami kényszerü leállás miatt szakadás következett be a beton folyamatosságában. Ezeket az üregeket elvileg utólag ki kellett tölteni (vagy kitöltötték, vagy nem), de a kitöltő anyag mindenképp gyengébb volt, mint az eredeti beton. E hatások miatt a beton egyenletessége nem mindig biztosított.

Ha egy rúdszerkezetnél súlyos betonozási hiba fordul elö, akkor az jelentősen lerontja a betonrúd teherbírását. Ha viszont a lokális betonhiba felületszerkezetben (lemez, fal, héj) található, a helyzet egészen más. Ez esetben ugyanis a gyengébb szakaszra kisebb teher jut, mert a rugalmassági tényezője is kisebb. Ezen kívül a hiba melletti jó minőségü szakaszok kisegítik a gyengébb szakaszt.

Ezért a szerkezet teherbírása kevésbé gyengébb, mint amit a betonhiba alapján vélnénk. A szerkezet értékelésénél mindig figyelembe kell vennünk, hogy a beton minősítési szabvány előírások minősítési értékei a betonanyagra vonatkoznak, és nem a szerkezet betonjára. A szerkezet értékelése a felülvizsgáló szakértő feladata és felelőssége. Jól alkalmazható a valószínűségelmélet alapján kialakult, évtizedek óta alkalmazott eljárás, hogy a vizsgálati mintasokaságból a 30\%-nál nagyobb eltérésủ elemeket kiküszöbölik. A szerkezet értékelése során, természetesen nem a próbatestek, hanem a beépített beton vizsgálati értékeit kell figyelembe venni.

\section{A SILÓKON FELLÉPETT REPEDÉ- SEK}

Az ÉTI keretében végzett kutatásai során (Pálossy, 1989) többek között felmérte egy sereg magyarországi siló repedezettségét. A silókon függőleges és vízszintes repedések jelentkeztek. A felmért 19 silón a következő maximális felületi repedéstágasságokat észlelték (A helynév melletti szám a maximális repedéstágasság mm-ben.):Szekszárd II: 0; Jászberény: 0; Enying: 0; Baja:0,3; Nagykáta: 0,4;

Fig. 1: A debreceni siló egyik cellájának repedésképe

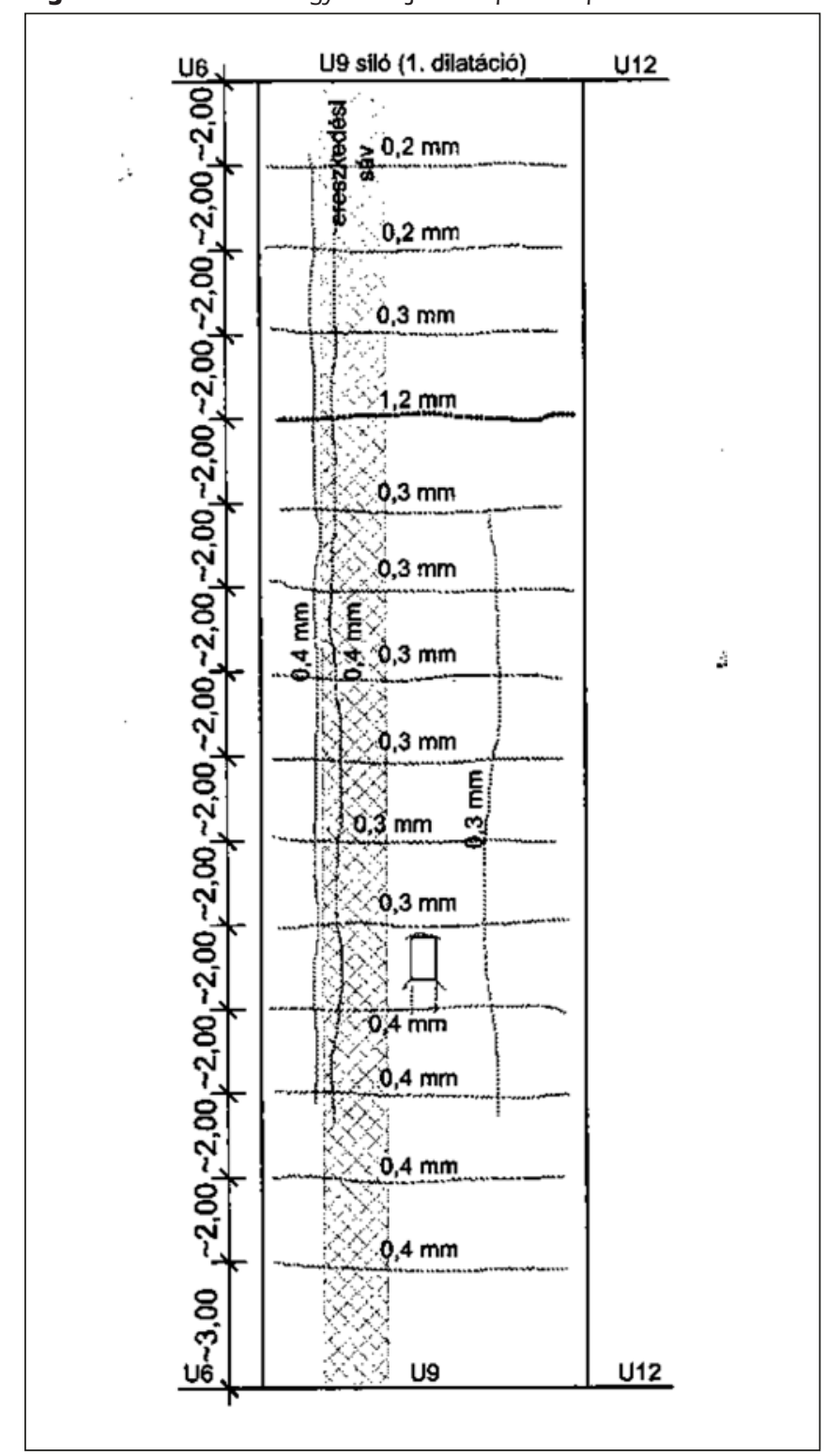


Székesfehérvár: 0,6; Hódmezővásárhely: 1,4; Cegléd: 1,4; Csorna: 1,5; Püspökladány:1,5; Marcali 1,8; Szentes: 2,0; Kecskemét:2,5; Törökszentmiklós: 2,5; Dombóvár:2,5; Karcag: 3,0; Szekszárd I.: 4,0; Miskolc: 5,0; Szeghalom: 5,0. Látható, hogy majdnem mindegyik silónál a maximális repedéstágasság jelentősen meghaladta a Vasbetonszabványban, ill. a Gabonatröszt Háziszabványban megadott $0,2 \mathrm{~mm}$ tervezési értéket. Érdekessége a méréseknek, hogy néhány silónál évenként mérték a maximális repedéseket, és ugyanazon silókon ugyanazon a helyeken a különböző években jelentősen eltérő maximális repedéseket észleltek. A vizsgált silók 19\%ánál 0,3-1,2 mm, 38\%-ánál 1,2-2,2 mm, 25\%-ánál 2,2-3,1 mm, 6\%-ánál 3,1-4,0 mm, és $12 \%$-ánál 4,0-5,0 mm volt a repedés. Megállapították a vizsgálatok során azt is, hogy ott voltak nagyobbak a függőleges repedések, ahol a méretezéskor a gyürüvasalást a határfeszültségig kihasználták, ill. ahol a javasolt 1,3 biztonsági tényezőnél kisebbet alkalmaztak. A kutatás azt is kimutatta, hogy a tönkremenetelek esetében a megelőző repedéstágasság 7-8 mm volt. A vízszintes repedések egymástól rendszerint (függőlegesen értve) mintegy 2,0 méter távolságokban jelentkeztek. Mindezekből az látszik, hogy a Gabona Tröszt Házi Szabványban (1989) a megfelelőségre megadott $0,2 \mathrm{~mm}$, illetve a türési határnak megszabott 0,6 $\mathrm{mm}$ értékek illúziónak tünnek, és ezen értékeket újra kellene gondolni, pl. az értékek 3-4 szeresére. Természetesen ezekben az esetekben megfelelő felületvédelmet kell alkalmazni. A repedésjelenség szemléltetéseként bemutatjuk a debreceni siló egyik felmért repedésképét (Takács-Kotró-Várdai, 2017). A függőleges repedések először a támrudaknál jelentkeztek, az üreg miatti gyengítés hatásaként. A tapasztalatok szerint, ha csak támrudaknál jelennek meg repedések, akkor erőtani erősítésre nincs szükség, ha két támrúd repedés között a repedések száma a hármat eléri, ill. meghaladja, akkor részletes erőtani vizsgálat szükséges. A támrudaknál jelentkező repedések különösen veszélyesek, mivel az üreg miatti gyengítés átmenő repedést okoz. A csapó eső miatt az üregben víz gyülik össze, amit az üreg távolra is elvezet, ha nem alkalmaznak felületi védelmet.

\section{A REPEDÉSEK ELEMZÉSE}

Az 1960-as években kezdődött az alagútzsaluzatos épületek építése, melyeknek jelentős részét a BUVÁTI-ban (Budapesti Városépítési tervező Vállalat) terveztük. Az Outinord

Fig. 2: A kötéshő sajátfeszültsége okozta épületfali felületi repedés

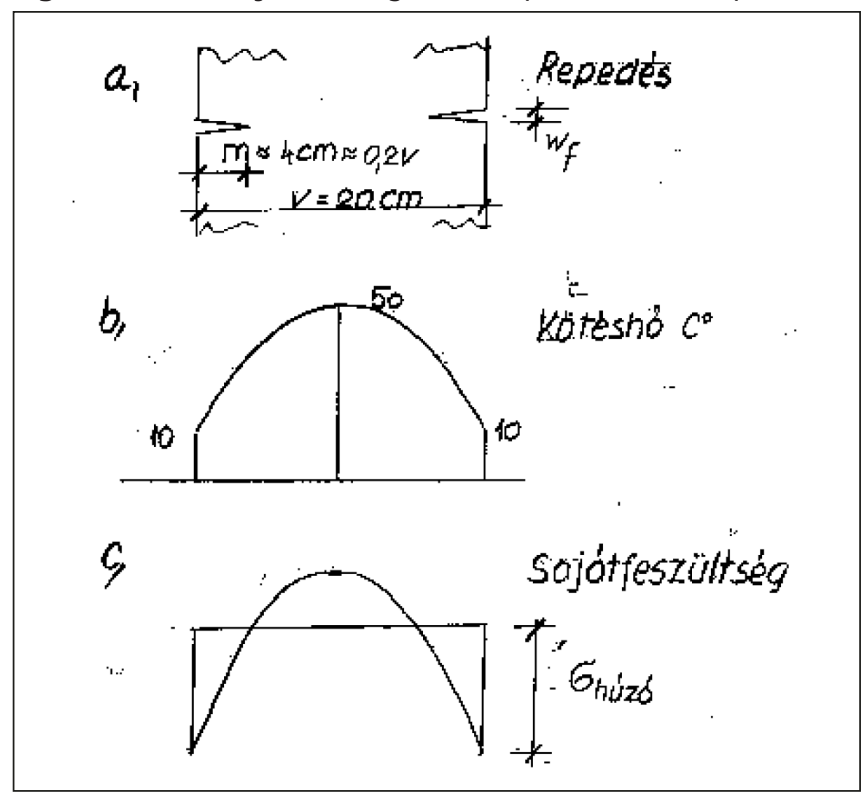

rendszerben az épületek kb. 6,0 méterre elhelyezkedö, $20 \mathrm{~cm}$ vastag vasbeton harántfallal épültek. A müvezetések során észleltük, hogy a falakon a bebetonozás után körülbelül egy héttel, mintegy 2,0 méter távolságban, 0,2-0,4 mm tágasságú repedések jelentkeztek. Miután a fal két oldalán a repedések más helyeken voltak, nyilvánvalónak látszott, hogy nem átmenő repedésekről van szó. A feltárások igazolták ezt, mert a repedések behatolási mélysége mintegy $3-4 \mathrm{~cm}$ volt. Addig ilyen repedésekről egyikünk sem hallott. A rejtélyt Palotás professzor egy előadása világította meg. A magyarázat szerint a viszonylag hideg idöben a beton mintegy $50{ }^{\circ} \mathrm{C}$ kötési hője a mintegy egy-két napos kizsaluzás után gyorsan áramlik a hidegebb felület felé, ez sajátfeszültségeket kelt. A fal felületén húzás keletkezik, és ez a még nem teljesen megszilárdult betonfelületet megrepeszti. A repedések a betonozás után mintegy egy héttel jelentkeznek, amikor is a rugalmassági tényező-húzószilárdság arány magasabb, mint később (Palotás, 1973.) A jelenséget a Fig.2.b ábrán mutatjuk be: Ha hőmérséklet-különbség értéke a $15^{\circ} \mathrm{C}$-t meghaladja, akkor repedés lép fel!

Az „a” ábra mutatja a betonfal kötéshő okozta felületi repedését, a „b”. ábra a kötéshő megoszlását a fal vastagsága mentén, a „c”. ábra pedig a sajátfeszültség megoszlását.

A silók esetében a megoszlás kissé módosul. Míg az épületfal esetében a hőmérsékleti viszonyok a fal mindkét oldalán egyformának vehetők, a silófalak építésénél ez nincs így. A külső oldal szabadon tud lehülni, amit még a mindig meglévő szélhatás is segít, a belső oldalon viszont kisebb a szélhatás, és a kötéshő a zártabb tér miatt magasabb hőmérsékletet okoz. E miatt a hőmérséklet és a sajátfeszültség aszimmetrikus lesz. A külső oldalon ezért nagyobb húzófeszültség ébredhet, mint a két oldalon hülő fal esetében (Fig. 3). Ha ez meghaladja a beton repesztő szilárdságát, a repedés kialakul.

A kötéshő okozta szélsőszáli húzófeszültség a számítások szerint az 1-2 N/mm² értéket is elérheti, ami megközelítőleg megegyezik a még meg nem szilárdult $\mathrm{C} 16$ beton repesztő feszültségével. Ez azt jelenti, hogy a silófal repedezettségének egyik oka ez lehet.

De nemcsak a kötéshő okozhat repedéseket. A repedéskeltő hatások az üzemelési körülmények következtében felléphetnek. A silóban tárolt gabona hőmérséklete az irodalom szerint 30$40{ }^{\circ} \mathrm{C}$, Ugyanakkor téli viszonyok között a külső hőmérséklet akár mínusz $10-15{ }^{\circ} \mathrm{C}$ is lehet. Ez a $30-50{ }^{\circ} \mathrm{C}$ höátmenet üzemi

Fig.3: A silócella kötéshő sajátfeszültsége okozta külső felületi repedése

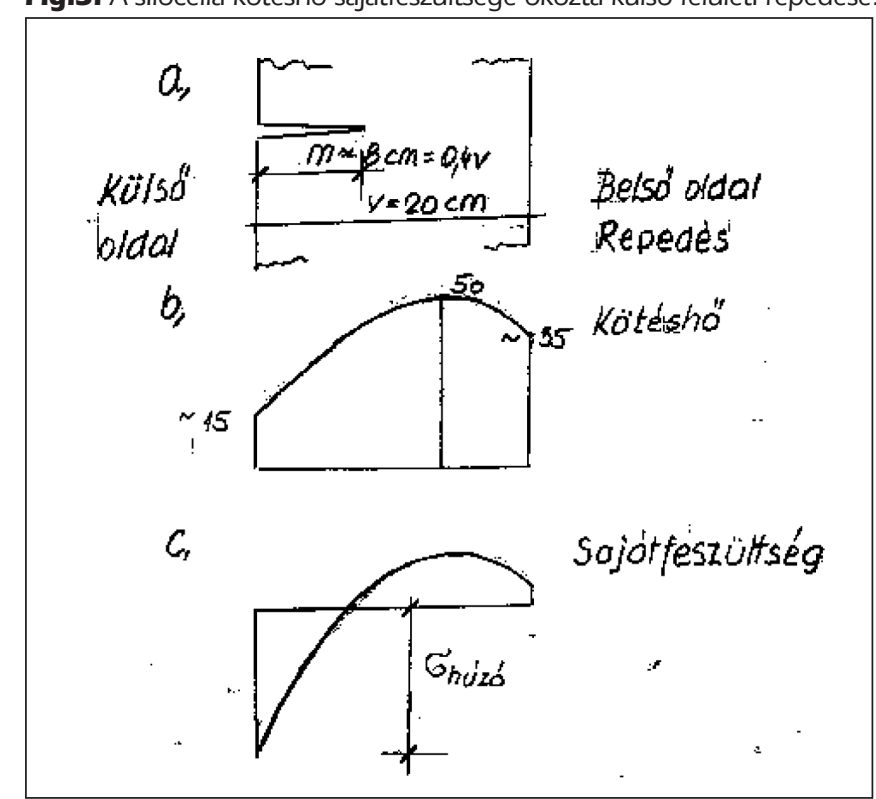




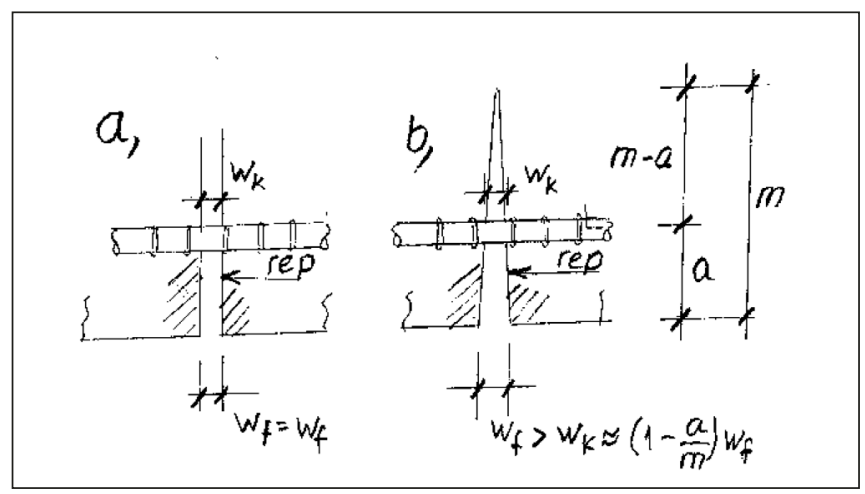

Fig. 4: $A$ felületi $w_{f}$ és a vastengelyi $w_{k}$ repedés

körülmények között 2-4 N/mm² húzófeszültséget okozhat, ami bőségesen elegendő a silófal megrepesztésére. (Ha véletlenül addig nem repedt volna meg.) Ezek a körülmények magyarázzák azt a korábban nem érthető jelenséget, hogy a Pálossy-vizsgálatok során, a különböző években és különböző időszakokban, ugyanazon a helyeken jelentősen különböző repedéstágasságokat mértek.

Az előírások a repedéstágasság korlátozására meghatározott repedési határértéket nem teszik függővé azoktól a hatásoktól, melyektől a repedéstágasság jelentősen függ. Arepedéstágassági korlátértékeket mindegyik elöírás (MSZ, DIN, Eurocode, Gabona Tröszt - Házi Szabvány (1989), stb.) a húzott acélbetét tengelyvonalára értelmezik $\left(\mathrm{w}_{\mathrm{k}}\right)$. A repedésméréseket pedig általában az ellenőrzéskor a felületen észlelt $\mathrm{w}_{\mathrm{f}}$ felületi repedéssel értelmezik. Ez igen jelentős eltéréseket okozhat. A problémát a következő Fig. 4. ábrán szemléltetjük. A silófal felülete napi és évszakos hőmérsékletváltozásnak van kitéve. (A Vasbetonszerkezetek Tanszéke, a Hódmezővásárhelyi siló függőleges falfelületén nyáron, $60^{\circ} \mathrm{C}$ hömérsékletet mért - üres siló esetén -, amíg a belső felület $18{ }^{\circ} \mathrm{C}$ volt.)

$\mathrm{Az}$ ábrán kétféle repedéstípust mutatunk be, melyek jelentősége és kárhatása eltérő. Az ,a” ábrán az úgynevezett átmenő repedés modellje látható, mely eset a tisztán húzott elemekre jellemző. Ez esetben a felületi repedéstágasság jó közelítéssel megegyezik a vastengelyi repedéstágassággal. (A valóságban kicsit nagyobb, mert a betonacél gátolja a nyúlást.) Ilyen repedés alakulhat ki a tisztán húzott vasbetonelemekben, ha a húzófeszültség a repesztő húzószilárdságot meghaladja. Ez a repedéstípus nemcsak a vaskorrózió szempontjából jelent veszélyt, hanem az átmenő repedésen át (ha nincs felületi védőbevonat) a csapóeső vize a siló belső terébe hatolhat, és károsítja a tárolt gabonát.

A,,b” ábrán pedig a felületi repedés egyszerüsített modellje látható. Ilyen típusú repedés alakul ki a hajlított elemek esetében, ahol az „m” méret közelítően a keresztmetszeti magasság felének vehető. Ugyanilyen típusú repedések alakulhatnak ki a kötési hő okozta saját feszültségek, valamint a zsugorodás okozta felületi repedések esetében. A repedés behatolás „,m” mérete 40-80 mm közötti szokott lenni. Ezekben az esetekben a vastengelyi repedés (melyre a korlátozások vonatkoznak) mindig kisebb, mint a felületi repedés. Ha pl. az „a” vasmélység $30 \mathrm{~mm}$, és a repedés behatolási „m” értéke 60 $\mathrm{mm}$, akkor a mértékadó „, $\mathrm{W}_{\mathrm{k}}$ ” repedés mérete fele a felületen mérhető „, $\mathrm{W}_{\mathrm{f}}$ ” repedéstágasságnak. Miután a silófalban nem lép fel számottevő hajlító nyomaték, a második két repedési ok lehet a mértékadó.

Ki kell emelni, hogy a kötéshö és a zsugorodás hatása az építés idején, ill. rövid idővel az építés után jelentkezik. A napi és évszakos hőmérséklet és az üzemelés (betárolás, ürítés) okozta repedezettség a siló egész élettartama alatt müködik, a repedések „élnek”, a védekezés elkerülhetetlen.
Egy másik felületi repedés a zsugorodási repedés. A zsugorodás jelensége (Fenyvesi, 2012) szerint a következőképp írható le:

„Korai vagy kapilláris, vagy képlékeny zsugorodás a beton friss, képlékeny állapotában lép fel, és létrehozza a kapillárisokat. A bedolgozott friss beton az első rövid idó alatt általában duzzad, de amikor a felületéröl a vízilm eltünik, elkezd zsugorodni. A korai zsugorodás gyors, rövid folyamat, a kötési idö végén (ez általában nem több mint 8 óra) véget ér. A keletkezö repedések felületi hajszálrepedések, tágasságuk 1-2 mm-t is elérhet, kedvezötlen klimatikus viszonyok közepette összértékük $4 \mathrm{~mm} / \mathrm{m}$ is lehet, de mélységük csekély, a megszikkadó felületi zónára korlátozódik. (A felület közeli tartományban húzások lépnek fel, míg a keresztmetszet belseje nyomás alatt áll.) Száradási zsugorodás a kötés végén, a szilárdulás kezdetén indul és egy évig is eltarthat, tehát egy lassú folyamat, amely végértékhez tart. Ezalatt a cementkö pórusai kiszáradnak, a teljesen kiszáradt beton nem zsugorodik tovább."

A zsugorodás okozta belső sajátfeszültségek hasonlóak a kötéshő csökkenés okozta feszültségekhez. Mindkettőnél húzás keletkezik a beton felületén, ami repedést okozhat. Ha a beton megrepedezett a hőmérsékleti hủlés miatt, akkor a zsugorodási repedés valószínúleg a repedés növekedésében fog jelentkezni. Ha viszont a beton nem repedt meg korábban, akkor új repedések jelentkezhetnek a zsugorodás hatására. A repedések megjelenése az időjárástól, a külső hőmérséklettől, és a légnedvességi értékektől függ. A silók függőleges irányban, kb. 2,0 méterenként jelentkezö, 0,3 mm körüli vízszintes repedéseinek oka a csúszó-zsaluzati hatásokon kívül a tárgyalt kétféle okban is keresendő. A vízszintes repedéseknél a húzóerő hatása kizárt, mert a silófalak függőleges irányban nyomottak, és a repedések a nyomóerőre merőlegesen jelentkeznek. A vízszintes felületi repedések hasonlóak a vasbeton falas épületek falaiban 2,0 méterenként jelentkező, 0,3 mm körüli, kötéshő és zsugorodás okozta repedésekhez. Ez valószínüsíti, hogy a silók vízszintes repedéseinek ugyanez a fö oka, és nem pedig a csúszózsaluzati hatás. A függőleges irányú repedésekben a gyürüirányú húzásoknak számottevő hatásuk lehet, de az is lehetséges, hogy az aszimmetrikus belső nyomás, és esetleg az égtájhatás (napsütés) okozta gyürüirányú hajlító nyomatékok repesztő hatása is hozzájárul a kialakulásukhoz. A jelentős gyürüirányú húzás hatására a függőleges repedések átmenő repedés jellegűek, ezek tágassága az üzemeltetés hatásai során (betárolás, ürítés) jelentősen változik.

\section{JAVÍTÁS}

A silók javítására több javaslat található a szakirodalomban (Orosz, 2001), (Bárczi, 2015), (Gabona Tröszt Házi Szabvány, 1989). Megvalósult javítások, ill. megerősítések ismertetései is találhatóak, (Almási, J. és társai, 2002), (Bucur-Horváth,Mátyás, 2007).

Véleményünk szerint, ha a szakértői vizsgálat megállapítja, hogy a repedések tágasságai az acélbetétek tengelyében nem haladják meg a (téli, nyári vizsgálat, töltéskori, ill. üres állapot) türési határt (szerintünk: 2,5 mm), akkor nem várható törési tönkremenetel, és elegendő a repedésjavítás, és a felületi védőréteg felhordása

Ha viszont a függőleges, átmenő repedések tágassága túllépi a türési határt, akkor gyürüirányú erősítés indokolt. Ennek módjára, Orosszal (2001) egyetértésben a felületvédelmen kívül a teljes húzóeröre méretezett belső vasbetonbélés erőtanilag a lehető legjobb megoldás, azonban építéstechnológia szempontjából a legkedvezőtlenebb. 
Az átmenő repedések jelenléte - felületvédelem nélkül - a legjelentősebb hibaforrás, mivel ezeken keresztül a csapó eső a cellába bejut és a gabona jelentős károsodását idézi elő. A cellafalra feltapadó tárolt anyag penészesedése miatt a teljes anyag átpenészesedik és emberi fogyasztásra alkalmatlanná válik, az értékcsökkenés így rendkívül jelentős.

Tárgyalásunkban nem foglalkoztunk a silólétesítmények egyéb szerkezeteivel. Ha ezek károsodottak, akkor természetesen javítani kell őket.

\section{MEGÁLLAPÍTÁSOK}

A silókon fellépett repedéseknek számos oka van. Az igénybevételekből a vasak tengelyvonalára történő repedésszámítás illúzió, mert az egyéb hatásokból jelentkezö repedések mérete összemérhető ezekkel. A vizsgálatoknál meg kell különböztetni az átmenő, és a felületi repedéseket, mert az átmenő repedések lehetnek igazán veszélyesek. A felületen mért repedéstágasságok félrevezetőek, mert rendszerint jelentősen nagyobbak a vastengelynél mérhető, az elöírások szerinti mértékadó repedéstágassággal.

A svéd tapasztalati képlet: $\mathrm{A}_{s} \geq 0,25 \mathrm{D}^{2}$ szerinti gyürüirányú, vízszintes acélbetét mennyiség alkalmazása a 7,3 m belső átméröjü cellák, és a ma szokásos acélok alkalmazása esetén azt jelenti, hogy az acélt legfeljebb a határfeszültség (tervezési szilárdság) negyedéig használjuk csak ki. (Itt $\mathrm{A}_{\mathrm{s}}$ az egy folyóméterre jutó gyürüvas keresztmetszet $\mathrm{cm}^{2}$-ben, és $\mathrm{D}$ a köralakú silócella belső átmérője m-ben.)

Álom, de jó lenne egy olyan eljárás, vagy müszer, amivel a felületi repedések mélységét meg lehetne mérni, hogy a felületi $\mathrm{w}_{\mathrm{f}}$ repedés szélességből pontosabban megállapíthassuk a mértékadó vastengelyi $\mathrm{w}_{\mathrm{k}}$ repedéstágasságot

A függőleges átmenő jellegü repedések tágassága a hőmérsékleti és üzemeltetési hatások miatt a siló egész élettartama alatt változik. Az ezeken a repedéseken át bejutó csapadékvíz károsító hatása ellenei védekezés érdekében, kiváló tulajdonságú, rugalmas repedésáthidaló képességü felületvédő bevonatot kell alkalmazni és azt időszakosan felújítani.

\section{HIVATKOZÁSOK}

Almási J. és társai (2002), „A törökszentmiklósi 800 vagonos gabonasiló megerösítése pp müszál adagolású lövellt betonnal”, VASBETONÉPÍTÉS, 2002/2, pp. 50-57.

Bárczi B.: (2015) Silók tönkremeneteli módjai, vasbeton silók megerősítési lehetőségei, PREZI (Internet)

Binnewies, W.-Hille, G.:(1983), „Belastung von Silozellen durch Siloguteinsturz", Bautechnik 11. 380. old.

Bölcskei E. - Orosz Á. (1970), „Vasbeton silók számítása”, TTI tervezési segédlet $\mathrm{S} 3$., Budapest

Bölcskei E.- Orosz Á.(1972): Vasbeton szerkezetek. Faltartók, lemezek, tárolók. Tankönyvkiadó. Budapest.

Bucur-Horváth I.-Mátyás Gy. (2007) : Vasbeton silók jellegzetes károsodása és megerösítése I rész. Beton, 6. szám. 3-7 old.

Bucur-Horváth I.-Mátyás Gy. (2007): Vasbeton silók jellegzetes károsodása és megerősítése II. rész. Beton, 2007/7-8. 10-13 old.

Dulácska, E. (1980).: A vasbetonszerkezetek repedései a beton zsugorodásának és lehülésé nek hatására. Mélyépitéstudományi Szemle, 1980/11, pp. 502-503.

Dulácska, E. (1991), „Szakértői vélemény a Tolna Megyei Gabonaforgalmi és Malomipari Vállalat dombóvári önálló malomtelepén lévő 20000 tonnás gabonasiló károsodásáról”, BME Szilárdságtani Tanszék, Budapest.

Dulácska, E. (1992), ,Szakértői vélemény a Tolna Megyei Gabonaforgalmi és Malomipari Vállalat a szekszárdi I. sz. silójával kapcsolatos peres ügyhöz”, BME Szilárdságtani Tanszék. Budapest.

Fenyvesi O. (2012)", A betonok korai repedésérzékenysége", PhD értekezés, BME Epitőanyagok és Mérnökgeológia Tanszék, Budapest
Gabona Tröszt - Házi Szabvány (1989), „Gabonatároló silók erőtani (statikai) ellenőrzése és tervezése, Budapest.

Kollár, L. (1989), „Silók méretezése”, TTI tervezési segédlet S-32. Budapest Palotás, L. (1973), „A vasbeton elmélete”, Akadémiai Kiadó, Budapest

Pálossy, L. (1989), „A Gabona Tröszt kezelésében lévő gabonatároló vasbetonsilók müszaki ismertetése. A tervezési és építési tapasztalatok", Témaszám: 13019, Építéstudományi Intézet, Budapest

Pálossy, L. (1989): Gabonatároló vasbetonsilókkal kapcsolatos hazai és külföldi kutatások összefoglaló elemzése, kiegészítése. I. és II. rész. Témaszám: 13019. Építéstudományi Intézet, Budapest

Rosemeier, G.(1986), „Zur Bestimmung des maximalen inneren Silódrucks”, Bautechnik 11, pp. 392-398.

Orosz Á. (2001). „Vasbeton silók javítási módszerének megválasztása”, BME Hidak és Szerkezetek Tanszék Tudományos Közleményei, Budapest, pp. 145-150.

Orosz Á. (1998), „Megjegyzések a silónyomás számításához gabonasilók esetében", $B M E$ Építőmérnöki Kar. Vasbetonszerkezetek Tanszék Tudományos Közleményei, Budapest, pp. 172-180.

Takács-Kotró-Várdai (2017), „Szakértői vélemény a Gabonatároló és Logisztikai Kft. debreceni telephelyén található, $42 \mathrm{db} 1000 \mathrm{~m}^{3}$-es vasbeton silót tartalmazó üzemi épület tartószerkezeteiről”, ÉMI-TÜV SÜD Kft., Budapest

Zilch, K.- Zehetmeier, G. (2010), „Bemessung im Konstruktiven Betonbau”, Springer Verlag, Berlin-Heidelberg.

Dr. Dulácska Endre okl. építészmérnök, 1930-ban született. 1950-82 között a BUVÁTI, 1982-1992 között a Tervezésfejlesztési Intézet statikus mérnöke, szakági főmérnök. 1991-től egyetemi tanár a BME Építészmérnöki Kar Szilárdságtani és Tartószerkezeti Tanszékén, jelenleg Prof.Emeritus. A SÁMSON Építés-Statikai Kft. ügyv. igazgatója. A Müszaki Tudomány Doktora (1983), az MTA Földrengésmérnöki Nemzeti Bizottságának elnöke, és az Akusztikai Bizottság tagja. Számos korábbi szabvány kidolgozásában volt jelentős része. Szakmai munkásságát nyolc könyve, több mint 200 publikációja, és mintegy 200 épülete fémjelzi. Hivatkozottsága is 200 feletti. A Magyar Mérnöki Kamara választmányi tagja, a budapesti Mérnöki Kamara etikai és fegyelmi bizottság tagja, a Tartószerkezeti Tagozat elnökségi tagja. Munkássága elismerésekén Eötvös Díjat, Csonka emlékérmet, Akadémiai Díjat, Széchenyi Díjat, MTA Ötvös Koszorút, Palotás László Díjat, Köztársasági Érdemrendet, és az MMK-tól Zielinszky díjat, Kardos Andor díjat, és Aranygyúrú díjat kapott,

Dr. Bódi István (1954) okl. építőmérnök (1978,) matematikus szakmérnök (1982), PhD (1997), egyetemi docens (1987-) a BME Hidak és Szerkezetek Tanszékén. Kutatási területei: Vasbetonszerkezetek és hagyományos épületszerkezetek rekonstrukciója és megerősítése, faszerkezetek csomópontjainak modellezése. Oktatási tevékenysége mellett, rendszeresen végez tervezési és szakértési tevékenységet a mérnöki tartószerkezetek -elsősorban a magasépítési és a hídszerkezetek- területén, amelyekhez MMK jogosultsággal (SZÉS12, HT, ME-KÉ, ME-É, SZÉS1 és T) rendelkezik. Tartószerkezeti vezető tervező és mủemléki épületdiagnosztikai szakértő (210340), tagja továbbá a Mủszaki Igazságügyi Szakértői Testületnek. Aktív tagja az alábbi szakmai testületeknek: Az ACI (American Concrete Institute), az ACI 423-as számú albizottság „Előfeszített beton”, a fib Magyar Tagozata és a Magyar Mérnöki Kamara (BPMK), az „Eurocode 5 - MSZ NAD (Faszerkezetek)” szabványügyi bizottság elnöke. a „Schweizerische Arbeitsgemeinschaft für das Holz", valamint ügyvezető igazgatója a Construct Civil Kft. -nek és az Armatura 2000 Kft.-nek.

\section{CRACKS ON EXISTING REINFORCED CONCRETE SILOS} Endre Dulácska - István Bódi

Silos are tubular facilities that are usually of 5-10 metres in diameter and 10-40 metres high and which are used for storing powdery and grainy materials. The most common type of silo is the one used for storing grain crops and grains. These have been used since the 1800 s which were originally made of wood, walling and seldom of metals. According to a survey of the year 1916 there were already 330000 silos around the world.

After the invention of the reinforced concrete, silos made of this material spread widely; initially boxed, with a cylindrical shell structure of 15 to $20 \mathrm{~cm}$ in thickness. After the handovers of these silos it was perceived that cracks had appeared on them. On the outer surface of silos, especially on the lower third of its height vertical cracks and many times along the entire height horizontal cracks occurred every 2-3 meters for a significant part of silos built in Hungary. Most of the vertical cracks occurred in the lower third of the silos' height, where the internal pressures are the highest, and the pressure from the silos' weight and the friction of stored grain are significant.

The inquiry has also shown that $85 \%$ of the domestic silos are cracked and cracking is a regular phenomenon in other countries, in different circumstances at plants or factories as well. The report found that fracture-free silo practically does not exist. There are several reasons for cracking, and fracture distances prior to failure are between $5-7 \mathrm{~mm}$. This paper deals with tubular reinforced concrete silos and their damages. 